(C) 2017

\author{
Тригуб О. В., кандидат сільськогосподарських наук \\ Устимівська дослідна станція рослинництва \\ Інституту рослинництва ім. В. Я. Юр'єва НААНУ
}

Ляшенко В. В., кандидат сільськогосподарських наук

Полтавська державна аграрна академія

\title{
ДЖЕРЕЛА ГОСПОДАРСЬКИХ ТА СЕЛЕКЦЙНО-ЦННИХ ОЗНАК ДЛЯ СЕЛЕКЦІЇ ГРЕЧКИ ЗВИЧАЙНОЇ (FAGOPYRUM ESCULENTUM МOENCH.)
}

\section{Рецензент - доктор сільськогосподарських наук, професор П. В. Писаренко}

\begin{abstract}
У статті наведено результати вивчення гречки звичайної різного походження із Національної колекиії України протягом 2014-2016 років в Устимівській дослідній станиії рослинництва за характеристиками господарської придатності та морфологічними показниками. Застосовані методики вивчення та опису матеріалу дали змогу диференціювати колекиіииний матеріал $і$ виділити найбільш цінний, як джерела господарських та селекиійно-цінних ознак за різними напрямками селекційного використання - за урожайністю та ї̈ складовими, якістю продукиії.
\end{abstract}

Ключові слова: гречка, урожайність, продуктивність, крупноплідність, озерненість, скоростиглість, низькорослість, відношення довжини зони гілкування до зони плодоутворення.

Постановка проблеми. Підвищення врожайності та іiі стабілізація по роках вирощування головна проблема сучасного сільського господарства, яка торкається всіх культур, що знаходяться у виробництві. Особливо актуальною вона $є$ для тих сільськогосподарських культур, які в останні роки не мали значного прогресу в поліпшенні своїх урожайних характеристик, але завдяки своїм природним споживчим властивостям займають чільне місце, є традиційними для певних регіонів розповсюдження. Для України це в першу чергу гречка, продукція з якої - крупа, стала мірилом достатку та стабільності, а коливання цін на гречану продукцію є суттєвим барометром життя суспільства. Сумарне виробництво гречаної продукції визначається в Україні не стільки попитом на неї - він в останні роки завжди високий, скільки привабливістю сортового потенціалу цієї культури, який за вимогами виробничників повинен нести в собі декілька визначальних складових: високу та стабільну урожайність, можливість пожнивного застосування культури i наявність привабливості для бджіл (що забезпечить високий медозбір і стабілізацію запилення і озерненість рослин) [9].
Аналіз основних досліджень і публікацій, у яких розпочато розв'язання проблеми. Враховуючи значне народногосподарське значення гречки, як традиційної національної культури, іiі цінність як незамінного продукту харчування, одного 3 найбільших медоносів, важливої ланки сівозміни та джерела матеріалів для переробної промисловості, останнім часом виробництву гречаної продукції в нашій країні приділяється значна увага. Дефіцит такого продукту харчування, як гречана крупа, невиправданий ріст цін на неї, вимагає від виробничників різкого підвищення обсягів виробництва гречки, який можливий, в першу чергу, не завдяки збільшенню площ, а шляхом підвищення урожайності посівів. Низька продуктивність гречаної рослини обумовлена іii біологічними характеристиками, які сформувалися в процесі еволюційного розвитку, під час просування гречки із ареалу ії виникнення до сучасних регіонів вирощування. Незважаючи на вагомий вплив селекції на сучасний стан гречки, не вирішеними залишаються питання стабілізації обсягів виробництва, різке зниження урожайності в несприятливі за воднотемпературним режимом роки. Особливо гостро це проявилося в останні 2-3 роки коли недостатнє виробництво гречаної продукції було обумовлено не лише зменшенням посівних площ під гречкою, а й підвищеними температурами та відсутністю опадів у літні місяці в основних гречкосіючих районах нашої країни [9].

Дослідженнями цілої плеяди вітчизняних та зарубіжних вчених - дослідників гречки протягом останнього століття, зроблено вагомий внесок у розуміння біології культури та причин низької урожайності гречаної рослини $[1-4,6,7]$. Але проблема низької стабільності врожайності залишається актуальною і сьогодні. Причиною чого може слугувати звужений поліморфізм гречки за низкою важливих для селекції характеристик, відсутність у селекціонерів-практиків вихідного матеріалу із господарськи цінними показ- 


\section{СІЛЬСЬКЕ ГОСПОДАРСТВО. РОСЛИННИЦТВО}

никами, стабільними чи пластичними в залежності від напрямку використання.

Вирішити проблеми стабілізації продуктивних характеристик гречки можливо через доскональне і всебічне дослідження накопиченого протягом майже 90 років колекційного матеріалу в Національній колекції гречки, основна частина якого розміщена на Устимівській дослідній станції рослинництва Інституту рослинництва ім. В.Я. Юр'єва НААН. Загальний обсяг колекції станції становить 1624 зразки. Головною цінністю цього зібрання є широке еколого-географічне представництво, наявність зразків селекційного походження та місцевих сортів і форм народної селекції, видового різноманіття роду Fagopyrum Mill. Роботи по вивченню цього різноманіття на дослідній станції мають також свої традиції, широку матеріальну та методичну базу, а також досвід накопичений колективом протягом 60 років роботи з генетичними ресурсами рослин.

Мета досліджень: виділення із наявного генофонду Національної колекції гречки, на основі раніше проведених досліджень, групи перспективних зразків та їх всебічна оцінка за комплексом господарських та селекційно-цінних ознак.

Під час проведення роботи було вирішено низку завдань: виявлення найбільш цінних зразків за рівнем вираження показників, проведення порівняльної характеристики генофонду за продуктивними та адаптивними показниками, розподіл колекційного матеріалу на групи за напрямками селекційного чи господарського використання.

Матеріал і методи досліджень. Для вивчення екологічно різноманітного колекційного матеріалу, оцінки його адаптивного потенціалу відповідно до угоди між Устимівською дослідною станцією рослинництва та Полтавською державною аграрною академією, на дослідній станції протягом 2014-2016 років проводилася закладка контрольного розсадника, де оцінювалася мінливість урожайних та супутніх до них характеристик зразків колекції, елементів архітектоніки рослин.

Для опису урожайних параметрів застосувалися характеристики маси зерна $3 \mathrm{~m}^{2}$ та рослини, крупність зерна, індексний показник озерненості суцвіть, а також показник тривалості вегетаційного періоду. Для опису архітектоніки вегетативної системи зразків застосовували показники висоти рослини, прикріплення нижніх гілок i суцвіть, кількості гілок на рослині, кількості вузлів на стеблі, кількості суцвіть на рослині, індексний показник відношення зони плодоношення до зони гілкування.
До дослідження включено набір колекційних зразків гречки звичайної (Fagopyrum esculentum Moench.) в кількості 153 шт. (з них 83 з України, 3 - 3 Литви, по 1 - $з$ Польщі та Франції, 19 - Республіки Білорусь, 43 - Російської Федерації, 3 Японіiі). За стандарт було використано національні стандарти - сорти Антарія та Оранта. Сортозразки розміщувалися за принципом латинського прямокутника за повної рендомізації розміщення ділянок у повтореннях. Зразки висівалися в оптимальний строк (14-16 травня) в колекційному розсаднику ручним способом на ділянках площею 4,05 м², 3 міжряддями 0,45 м по 50 насінин на погонний метр. Сорти-стандарти висівали через кожні 10 номерів колекційних зразків. Фенологічні спостереження, та обліки, морфологічний опис, класифікацію за рівнем прояву господарсько-цінних ознак та біологічних властивостей проводили відповідно «Широкого уніфікованого класифікатора роду Гречки (Fagopyrum esculentum Moench.)» [11] та «Методика проведення експертизи сортів гречки їстівної (Fagopyrum esculentum Moench) на відмінність, однорідність і стабільність» [5]. Польові досліди розміщувалися в селекційно-насінницькій сівозміні, попередником виступав чистий пар та застосовувалася загально прийнята технологія вирощування гречки.

Метеорологічні умови, що склалися під час вегетації періоду вивчення матеріалу, вирізнялися значною різноманітністю і дали змогу в повній мірі оцінити потенціал зразків за продуктивними, якісними та адаптивними характеристиками. Найбільш сприятливими для росту та розвитку рослин були умови 2015 року, коли спостерігалися підвищені в порівнянні з середньо багаторічними показниками параметри температури $\left(+2,2{ }^{0} \mathrm{C}\right.$ за веґетаційний період по середньодобових температурах, 3 відхиленнями від $+1,2$ у квітні до $+3,2{ }^{0} \mathrm{C}$ у серпні) та значними, хоч i нерівномірно розподіленими опадами у весняні та літні місяці (загальна кількість опадів за квітень-серпень становила 276,6 мм 3 недостачею у серпні 49 мм (-84,5\% до норми) і надлишком у червні 66,5 мм (+116,7 \% до норми)). Відзначений надлишок вологи у червні не мав негативного впливу на рослини гречки, бо припадав на період інтенсивного вегетативного розвитку рослини зі значною потребою у волозі. Серпнева недостача вологи вже припала на період закінчення вегетації та збирання врожаю. Погодні умови 2014 та 2016 років виявилися більш складними за водно-температурним режимом. Особливо умови 2014 року, коли на фоні підвищених у порівнянні 3 середньобагаторічними показниками, температур (від $+1,1{ }^{0} \mathrm{C}$ в червні до $+4,2{ }^{0} \mathrm{C}$ у липні), спостері- 


\section{СІЛЬСЬКЕ ГОСПОДАРСТВО. РОСЛИННИЦТВО}

галася недостача вологи (242,6 мм, 3 дефіцитом 38,4 мм до середньобагаторічних). Крім того, негативний вплив у 2014 році спричинили значні вітри та дощі з градом, які відмічені в кінці червня та на початку липня. Більшість зразків мали значне вилягання рослин, а задовільного рівня врожай не був отриманий через знищення квітів, суцвіть та гілок на рослинах. У 2016 році сумарні показники метеорологічних умов були дещо кращими, але досить жорсткими виявилися умови під час генеративного розвитку рослин. Липень мав на $3,0{ }^{\circ} \mathrm{C}$ вищу середньодобову температуру і на 34,5 мм меншу кількість опадів від середньобагаторічних показників.

Результати досліджень. У результаті вивчення та порівняльної оцінки різноманітного за екологогеографічним походженням колекційного матеріалу було виділено цінні зразки, що є джерелами селекційно важливих характеристик та індексних показників опису рослинного матеріалу гречки.

Для селекційної практики, за даними низки вітчизняних та зарубіжних вчених, визначне значення має не лише абсолютне вираження показників урожайності зразків, а й значення характеристик, які їі формують (індивідуальна насіннєва продуктивність генотипів, виражена кількістю і масою зерен з рослини, а також крупність зерен i, що надзвичайно важливо для гречки, здатність до дружного достигання) $[8,1]$.

Проведене вивчення набору зразків дало змогу розподілити колекційний матеріал за урожайністю і виділити найбільш цінний серед них. Особливо цінними $є$ зразки, що в середньому за роки вивчення мали рівень урожайності понад 300 г/м² - UC0101960, Антарія (Київська обл.), UC0100971, UC0100998 (Полтавська обл.), UC0101006, Крупинка (Сумська обл.), UC0101981, Ювілейна 100 (Сумська обл.), UC0101200, Вікторія Подільська (Хмельницька обл.), UC0101198, Роксолана (Хмельницька обл.), UC0102114, Марта (Мінська обл.), UC0102195, СИН 3/02 (Київська обл.), UC0102179, Башкирская красностебельная (Башкортостан), UC0101993, Ярославна (Сумська обл.).

Аналіз показника ваги зерна 3 рослини дає змогу розподілити досліджуваний матеріал і виявити серед нього більш придатний для застосування у селекції для підвищення індивідуальної продуктивності рослин. До більш привабливого за цим показником можна віднести сортовий i місцевий матеріал походженням із України, а також сортовий матеріал останніх років селекції iз Російської Федерації та Республіки Білорусь. Продуктивність рослин (понад 3,0 г 3 рослини) мали зразки: UC0101960 (с. Антарія, Київська обл.), UC0102114 (с. Марта, Мінська обл.), UC0102195 (с. СИН 3/02, Київська обл.), UC0102179 (с. Башкирская красностебельная, Башкортостан), UC0101993 (с. Ярославна, Сумська обл.), UC0101981 (с. Ювілейна 100, Сумська обл.), UC0101200 (с. Вікторія Подільська, Хмельницька обл.).

Масу 1000 зерен (крупноплідність) відносять до важливих складових урожайності сортів гречки та вважають контрольним показником технологічності зразків [10]. За масою 1000 зерен у групі вивчення виділено зразки, крупність яких була оптимальною (за технологічними стандартами), на рівні 27-30 г. Загальна кількість таких зразків - 21 шт., найбільш стабільними серед них є UC0101960 (с. Антарія, Київська обл.), UC0100998, UC0101058 (Полтавська обл.), UC0101006 (с. Крупинка, Сумська обл.), UC0101853 (с. Радехівська T, Львівська обл.), UC0101200 (с. Вікторія Подільська, Хмельницька обл.), UC0102114 (с. Марта, Мінська обл.), UC0102195 (с. СИН 3/02, Київська обл.), UC0102179 (с. Башкирская красностебельная, Башкортостан), UC0101993 (с. Ярославна, Сумська обл.), UC0101981 (с. Ювілейна 100, Сумська обл.).

Кількість суцвіть на рослині є параметром, що характеризує потенційну продуктивність рослин, вказуючи на здатність формувати генеративну сферу рослини. Разом з тим індетермінантні сорти вирізняються підвищеною здатністю до формування суцвіть, але в кінцевому результаті незначною озерненістю їх, яка визначається як відношення кількості зерен на рослині до кількості суцвіть. Показник озерненості є більш інформативним для селекціонера, бо показує реальну віддачу в роботі генеративної сфери. Більшим індексом озерненості суцвіть (понад 5,0) вирізнялися зразки: UC0101960 (с. Антарія, Київська обл.), UC0100176 (с. Мінчанка, Мінська обл.), UC0100186 (с. Ударница, Амурська обл.), UC0100282 (Франція), UC0100963, UC0100971, UC0100998, UC0101058, UC0100340 (Полтавська обл.), UC0101006 (с. Крупинка, Сумська обл.), UC0101093 (с. Величавая, Орловська обл.), UC0100669 (с. Буринська, Сумська обл.), UC0100960 (с. Липово-Долинська, Сумська обл.), UC0101981 (с. Ювілейна 100, Сумська обл.), UC0101731 (с. Теребовлянська, Тернопільська обл.), UC0100906 (с. Полтавка, Полтавська обл.), UC0101853 (с. Радехівська Т, Львівська обл.), UC0101200 (с. Вікторія Подільська, Хмельницька обл.), UC0101642 (с. Детермінант 2, Полтавська обл.), UC0101165 (c. Grushowska, Польща), UC0101198 (с. Роксолана, Хмельницька обл.), UC0101978 (с. Приморская 7, Приморський кр.), UC0102114 (с. Марта, Мінська обл.), UC0102195 (с. СИН 3/02, Київська обл.). 


\section{СІЛЬСЬКЕ ГОСПОДАРСТВО. РОСЛИННИЦТВО}

Тривалість вегетаційного періоду є показником, що характеризує матеріал, як 3 позиції придатності до господарського застосування (основний, пожнивний посів, створення медоносного конвеєра тощо), а також дає характеристику потенціалу адаптивної пристосованості сортів. Зважаючи на погодні умови основних гречкосіючих регіонів України, сьогодні більш витребуваним є скоростиглий матеріал, здатний формувати хоч і менший в порівнянні 3 середньо- i пізньостиглим матеріалом урожай, але, який може більш повно використати вологу пізновесняного та ранньолітнього періоду на формування генеративної сфери, а не на ростові процеси. В загальному по групі вивчення тривалість вегетаційного періоду коливалася від 65 до
111 діб. Закономірно, більш пізньостиглими виявилися зразки походженням із Приморського краю (Російська Федерація) - представники пізньостиглої приморської групи (згідно з класифікацією А. С. Кротова, 1963) [3]. Розмах варіювання величини показника тривалості вегетаційного періоду у джерел скоростиглості (в середньому за три роки вивчення) становив від 67 до 69 діб. Найменшою (67 діб) величина вегетації виявлена у зразків із Литви (UC0101905), Гомельської обл. (UC0101768), Татарстану (UC0101118).

Із групи вивчення було виділено скоростиглий матеріал (як потенційне джерело високоінтенсивного вихідного матеріалу), який мав вегетаційний період на рівні 65-70 діб (таблиця 1).

\section{1. Скоростиглі зразки гречки (за даними 2014-2016 років)}

\begin{tabular}{|c|c|c|c|c|c|}
\hline \multirow{2}{*}{$\begin{array}{c}\text { № Національного } \\
\text { каталогу }\end{array}$} & \multirow{2}{*}{$\begin{array}{l}\text { Назва } \\
\text { зразка }\end{array}$} & \multirow{2}{*}{$\begin{array}{c}\text { Країна } \\
\text { походження }\end{array}$} & \multicolumn{3}{|c|}{ Тривалість вегетаційного періоду, діб } \\
\hline & & & середнє & $\min$ & $\max$ \\
\hline 1 & 2 & 3 & 4 & 5 & 6 \\
\hline UC0100653 & Хоростківська & TRN & 69 & 66 & 72 \\
\hline UC0100669 & Буринська & SUM & 69 & 68 & 72 \\
\hline UC0101725 & & LVV & 69 & 66 & 71 \\
\hline UC0101829 & & ZAK & 69 & 66 & 72 \\
\hline UC0101376 & & HML & 69 & 66 & 72 \\
\hline UC0101461 & & HML & 69 & 67 & 72 \\
\hline UC0101326 & & HML & 69 & 68 & 72 \\
\hline UC0101406 & & HML & 68 & 66 & 70 \\
\hline UC0101982 & & HML & 69 & 66 & 72 \\
\hline UC0101402 & & HML & 69 & 66 & 73 \\
\hline UC0101426 & & HML & 68 & 66 & 71 \\
\hline UC0101288 & & HML & 69 & 66 & 71 \\
\hline UC0101397 & & HML & 69 & 66 & 72 \\
\hline UC0101249 & & HML & 69 & 66 & 72 \\
\hline UC0102200 & & RVN & 68 & 66 & 70 \\
\hline UC0102206 & Селяночка & SUM & 69 & 66 & 72 \\
\hline UC0101904 & місцевий 46 & Литва (LTV) & 69 & 67 & 71 \\
\hline UC0101905 & місцевий 57 & Литва (LTV) & 67 & 65 & 70 \\
\hline UC0101768 & & GML & 67 & 65 & 69 \\
\hline UC0101771 & & GML & 69 & 66 & 72 \\
\hline UC0101985 & Лєна & MNK & 69 & 66 & 72 \\
\hline UC0100068 & & TTR & 69 & 66 & 72 \\
\hline UC0100170 & Крупноплодная & $\mathrm{BSH}$ & 69 & 66 & 72 \\
\hline UC0100175 & & MSK & 68 & 65 & 71 \\
\hline UC0101118 & Казанка & TTR & 67 & 65 & 70 \\
\hline UC0101867 & & RA & 68 & 66 & 71 \\
\hline UC0101878 & & VLG & 68 & 66 & 70 \\
\hline UC0101909 & Мордовська 124 & MRD & 68 & 65 & 71 \\
\hline UC0101916 & & KRS & 69 & 65 & 71 \\
\hline UC0102180 & Ілішевская & $\mathrm{BSH}$ & 68 & 65 & 71 \\
\hline UC0102181 & Інзерская & BSH & 69 & 65 & 72 \\
\hline UC0101940 & & Японія (JPN) & 69 & 66 & 72 \\
\hline
\end{tabular}


СІЛЬСЬКЕ ГОСПОДАРСТВО. РОСЛИННИЦТВО

2. Низькорослі зразки гречки (за даними 2014-2016 рр.)

\begin{tabular}{|c|c|c|c|c|c|}
\hline \multirow{2}{*}{$\begin{array}{c}\text { № Національного } \\
\text { каталогу }\end{array}$} & \multirow{2}{*}{ Назва зразка } & \multirow{2}{*}{ Країна } & \multicolumn{3}{|c|}{ Висота рослини, см } \\
\cline { 4 - 5 } & & походження & середнє & min & max \\
\hline UC0100622 & 2 & 3 & 4 & 5 & 6 \\
\hline UC0101376 & & HRK & 85,6 & 62 & 99 \\
\hline UC0101326 & & HML & 85,4 & 68 & 100 \\
\hline UC0101426 & & HML & 85,8 & 76 & 94 \\
\hline UC0101249 & & HML & 81,6 & 75 & 132 \\
\hline UC0102200 & & HML & 86,8 & 68 & 108 \\
\hline UC0102207 & Руслана & SUM & 78,0 & 70 & 90 \\
\hline UC0100012 & місцевий 1 & Литва (LTV) & 85,6 & 71 & 98 \\
\hline UC0101904 & місцевий 46 & Литва (LTV) & 86,6 & 58 & 73 \\
\hline UC0101905 & місцевий 57 & Литва (LTV) & 59,4 & 63 & 125 \\
\hline UC0101768 & & GML & 74,0 & 47 & 80 \\
\hline UC0101771 & & GML & 80,4 & 48 & 98 \\
\hline UC0101791 & & MGL & 81,6 & 50 & 102 \\
\hline UC0101985 & Лєна & MNK & 83,0 & 73 & 94 \\
\hline UC0102203 & Аметист & MNK & 68,0 & 51 & 87 \\
\hline UC0102204 & Сапфір & MNK & 78,0 & 61 & 88 \\
\hline UC0100706 & & BSH & 86,8 & 58 & 107 \\
\hline UC0100068 & & TTR & 84,0 & 58 & 95 \\
\hline UC0101872 & & BRT & 86,4 & 82 & 95 \\
\hline UC0101878 & & VLG & 77,8 & 66 & 95 \\
\hline UC0102180 & Ілішевская & BSH & 75,0 & 67 & -94 \\
\hline UC0102181 & Інзерская & BSH & 81,2 & 68 & 104 \\
\hline UKR008:01687 & Батир & TTR & 72,2 & 59 & 83 \\
\hline UC0101940 & & Японія (JPN) & 71,6 & 62 & 81 \\
\hline
\end{tabular}

Важливим для гречки показником, який має безпосередній зв' язок з тривалістю вегетаційного періоду є висота рослин, яка також разом із параметрами нижнього міжвузля у рослин гречки $є$ індексним показником стійкості рослин до вилягання (за наявності дії вітрів). По групі вивчення висота рослини у зразків гречки варіювала в межах 42-174 см. Найбільш низькорослими виявилися зразки скоростиглої північної та середньостиглої південної екологогеографічних груп. За результатами виділено групу зразків висота рослини яких, в середньому за три роки, не перевищувала 87 см (таблиця 2).

Значна частина втрат під час збирання відбувається за рахунок низького розміщення гілок та нижнього продуктивного суцвіття, яке за вимогою технологічних стандартів повинно становити не менше 30 см від поверхні грунту. Із групи вивчення такими параметрами вирізнялися 36 зразків. Враховуючи варіювання величини цього показника у сортів до групи перспективних зразків було включено матеріал, який в різні за погодними умовами роки мав розміщення нижньої гілки на рівні понад 30 см та нижнього суцвіття на рівні понад $50 \mathrm{~cm}$, це - UC0100130, Комета (Приморський кр.), UC0100235, UC0100253, UC0100256, UC0101173 (Приморський кр.), UC0100282 (Франція), UC0100297 (Амурська обл.), UC0100971, UC0101021 (Полтавська обл.), UC0100442, Богатырь (Орловська обл.), UC0101981, Ювілейна 100 (Сумська обл.), UC0100884, Самбірська (Львівська обл.), $\mathrm{UC0100883,} \mathrm{Перемишлянська} \mathrm{(Львівська} \mathrm{обл.),}$ UC0101166, Гілея (Хмельницька обл.), UC0101978, Приморская 7 (Приморський кр.), UC0101977 (Японія), UC0101993, Ярославна (Сумська обл.), UC0102195, СИН 3/02 (Київська обл.).

Кількість гілок і суцвіть на рослині не $є$ прямими характеристиками урожайності сортів гречки, але вони $є$ селекційно важливими показниками потенціалу генофонду і можуть мати певний інтерес у науковців, які розробляють альтернативні напрями використання гречки. Особливо це стосується формування медоносного конвеєру гречки, вирощування гречки не лише для отримання зерна, а й сировини для 


\section{СІЛЬСЬКЕ ГОСПОДАРСТВО. РОСЛИННИЦТВО}

альтернативного палива, зеленого добрива тощо. Серед групи вивчення виділено матеріал, що вирізняється значною гіллястістю (кількістю гілок першого другого та інших порядків) та кількістю суцвіть. Це в першу чергу зразки із Російської Федерації (пізньостигла приморська група), а також матеріал місцевого походження i3 Республіки Білорусь та західних областей України. Рослини цих зразків сформували від 15 до 27 гілок та від 15 до 107 суцвіть на рослині. Коливання величини цього показника по роках виявлений у незначних межах. Найменша кількість гілок формувалася рослинами із північних районів Російської Федерації (Московська, Архангельська області), цей же матеріал виявився більш скоростиглим та низькорослим. Найменшу кількість суцвіть на рослині формували сучасні детермінантні сорти, що вказує на чітку диференціацію періодів росту у рослин, 3 генетично закріпленим розподілом у часі вегетативної та генеративної фази розвитку.

Вітчизняними вченими [9] було обгрунтовано доцільність використання у селекційній практиці показника відношення довжини зони гілкування до зони плодоутворення. Проведення добору за показниками величини вегетативної і генеративної маси дає змогу виявити такі форми, які в разі значного обмеження ростових процесів здатні сформувати високий урожай. Під час роботи 3 колекційним матеріалом важливим $\epsilon$ виявлення серед сортового різноманіття колекції тих сортозразків, які володіють більшою потенційною здатністю до формування врожаю за рахунок меншої генеративної сфери.

У процесі дослідження серед колекційного матеріалу було виділено групу зразків, які відрізняються найвищим показником співвідношення зони плодоношення до зони гілкування (таблиця 3).

\section{3. Зразки із високим співвідношенням зони плодоношення до зони гілкування}

(за даними 2014-2016 рр.)

\begin{tabular}{|c|c|c|c|c|c|}
\hline \multirow[t]{2}{*}{$\begin{array}{c}\text { № Національного } \\
\text { каталогу }\end{array}$} & \multirow[t]{2}{*}{$\begin{array}{l}\text { Назва } \\
\text { зразка }\end{array}$} & \multirow[t]{2}{*}{$\begin{array}{c}\text { Країна } \\
\text { походження }\end{array}$} & \multicolumn{3}{|c|}{$\begin{array}{c}\text { Співвідношення зони } \\
\text { плодоношення до зони } \\
\text { галуження }\end{array}$} \\
\hline & & & середнє & $\min$ & $\max$ \\
\hline 1 & 2 & 3 & 4 & 5 & 6 \\
\hline UC0101028 & & PLT & 1,97 & 1,69 & 2,36 \\
\hline UC0100649 & & TRN & 2,52 & 1,97 & 3,02 \\
\hline UC0100650 & & TRN & 2,04 & 1,59 & 2,44 \\
\hline UC0100653 & Хоростківська & TRN & 2,25 & 1,96 & 2,59 \\
\hline UC0100660 & & TRN & 1,92 & 1,47 & 2,34 \\
\hline UC0101725 & & LVV & 1,86 & 1,61 & 2,24 \\
\hline UC0101376 & & HML & 1,85 & 1,59 & 2,12 \\
\hline UC0101467 & & HML & 2,46 & 2,03 & 3,02 \\
\hline UC0101461 & & HML & 1,85 & 1,49 & 2,06 \\
\hline UC0101326 & & HML & 2,76 & 2,23 & 3,01 \\
\hline UC0101258 & & HML & 1,92 & 1,57 & 2,27 \\
\hline UC0101449 & & HML & 1,81 & 1,52 & 2,19 \\
\hline UC0101320 & & HML & 2,28 & 2,02 & 2,58 \\
\hline UC0101388 & & HML & 2,10 & 1,76 & 2,45 \\
\hline UC0101471 & & HML & 1,93 & 1,63 & 2,26 \\
\hline UC0101426 & & HML & 1,96 & 1,57 & 2,31 \\
\hline UC0101274 & & HML & 1,87 & 1,56 & 2,04 \\
\hline UC0102200 & & RVN & 2,68 & 2,06 & 3,04 \\
\hline UC0102207 & Руслана & SUM & 2,86 & 2,37 & 3,18 \\
\hline UC0100286 & Свитязянка & MNK & 2,15 & 1,84 & 2,39 \\
\hline UC0101195 & Ілія & MNK & 2,35 & 2,02 & 2,51 \\
\hline UC0102181 & Інзерская & $\mathrm{BSH}$ & 2,87 & 2,34 & 3,26 \\
\hline UKR008:01687 & Батир & TTR & 3,16 & 2,64 & 3,52 \\
\hline
\end{tabular}




\section{СІЛЬСЬКЕ ГОСПОДАРСТВО. РОСЛИННИЦТВО}

Висновки. Застосування відповідних методик вивчення колекційних зразків дає змогу серед сортового матеріалу селекційного походження та місцевих сортів та форм, виділити матеріал, що володіє значним потенціалом продуктивності та якості, диференціювати наявний генофонд на групи за рівнем вираження тієї чи іншої характеристики. На основі проведених досліджень було встановлено, що:

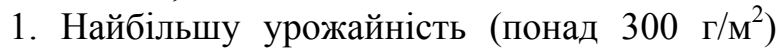
мають зразки UC0101960, Антарія (Київська обл.), UC0100971, UC0100998 (Полтавська обл.), UC0101006, Крупинка (Сумська обл.), UC0101981, Ювілейна 100 (Сумська обл.), UC0101200, Вікторія Подільська (Хмельницька обл.), UC0101198, Роксолана (Хмельницька обл.), UC0102114, Марта (Мінська обл.), UC0102195, СИН 3/02 (Київська обл.), UC0102179, Башкирская красностебельная (Башкортостан), UC0101993, Ярославна (Сумська обл.);

2. Більш продуктивними (понад 3,0 г з рослини) є зразки UC0101960 (с. Антарія, Київська обл.), UC0102114 (с. Марта, Мінська обл.), UC0102195 (c. СИН 3/02, Київська обл.), UC0102179 (с. Башкирская красностебельная, Башкортостан), UC0101993 (с. Ярославна, Сумська обл.), UC0101981 (с. Ювілейна 100, Сумська обл.), UC0101200 (с. Вікторія Подільська, Хмельницька обл.);

3. За масою 1000 зерен у групі вивчення виділено зразки, крупність яких була оптимальною (за технологічними стандартами), на рівні 27-30 г. Загальна кількість таких зразків - 21 шт., найбільш стабільними серед них є UC0101960 (с. Антарія, Київська обл.), UC0100998, UC0101058 (Полтавська обл.), UC0101006 (с. Крупинка, Сумська обл.), UC0101853 (с. Радехівська Т, Львівська обл.), UC0101200 (с. Вікторія Подільська, Хмельницька обл.), UC0102114 (с. Марта, Мінська обл.), UC0102195 (с. СИН 3/02, Київська обл.), UC0102179 (с. Башкирская красностебельная, Башкортостан), UC0101993 (с. Ярославна, Сумська обл.), UC0101981 (с. Ювілейна 100, Сумська обл.);

4. Показник озерненості $є$ більш інформативним для селекціонера, бо показує реальну віддачу в роботі генеративної сфери. Більшим індексом озерненості суцвіть (понад 5,0) вирізнялися зразки: UC0101960 (с. Антарія, Київська обл.), UC0100176 (с. Мінчанка, Мінська обл.), UC0101200 (с. Вікторія Подільська, Хмельницька обл.), UC0101642 (с. Детермінант 2, Полтавська обл.), UC0101165 (c. Grushowska, Польща), UC0101198 (с. Роксолана, Хмельницька обл.),
UC0101978 (с. Приморская 7, Приморський кр.), UC0102114 (с. Марта, Мінська обл.), UC0102195 (с. СИН 3/02, Київська обл.) та інші;

5. Із групи вивчення було виділено скоростиглий матеріал (як потенційне джерело високо інтенсивного вихідного матеріалу), який мав вегетаційний період на рівні 65-70 діб: UC0100653 (Хоростківська, Тернопільська обл.), UC0100669 (Буринська, Сумська обл.), UC0101725 (Львівська обл.), UC0101829 (Закарпатська обл.), UC0101376 (Хмельницька обл.), UC0101985 (Лєна, Мінська обл.), UС0100068 (Татарстан), UC0100170 (Крупноплодная, Башкортостан), UC0100175 (Московська обл.) та інші;

6. По групі вивчення висота рослини у зразках гречки варіювала в межах 42-174 см. Найбільш низькорослими виявилися зразки скоростиглої північної та середньостиглої південної екологогеографічних груп. За результатами виділено групу зразків, висота рослини яких, в середньому за три роки, не перевищувала $87 \mathrm{cm:}$ UC0101426 та UC0101249 (Хмельницька обл.), UC0102200 (Рівненська обл.), UC0102180 (Ілішевская, Башкортостан), UC0102181 (Інзерская, Башкортостан), UKR008:01687 (Батир, Татарстан), UC0101940 (Японія) та інші;

7. До групи перспективних зразків було включено матеріал, який в різні за погодними умовами роки мав розміщення нижньої гілки на рівні понад 30 см та нижнього суцвіття на рівні понад 50 см, це - UC0100130, Комета (Приморський кр.), UC0100235, UC0100253, UC0100256, UC0101173 (Приморський кр.), UC0100282 (Франція), UC0100297 (Амурська обл.), UC0100971, UC0101021 (Полтавська обл.), UC0100442, Богатырь (Орловська обл.), UC0101981, Ювілейна 100 (Сумська обл.), UC0100884, Самбірська (Львівська обл.), UC0100883, Перемишлянська (Львівська обл.), UC0101166, Гілея (Хмельницька обл.), $\mathrm{UC0101978,} \mathrm{Приморская} 7$ (Приморський кр.), UC0101977 (Японія), UC0101993, Ярославна (Сумська обл.), UC0102195, СИН 3/02 (Київська обл.);

8. Серед групи вивчення виділено матеріал, що вирізняється значною гіллястістю та кількістю суцвіть. Це, в першу чергу, зразки із Російської Федерації (пізньостигла приморська група), а також матеріал місцевого походження із Республіки Білорусь та західних областей України. Рослини цих зразків сформували від 15 до 27 гілок та від 15 до 107 суцвіть на рослині. Найменша кількість гілок формувалася рослинами із північних районів Російської Федерації (Московська, Архангельська області), цей же матеріал виявив- 
ся більш скоростиглим та низькорослим. Найменшу кількість суцвіть на рослині формували сучасні детермінантні сорти, що вказує на чітку диференціацію періодів росту у рослин, 3 генетично закріпленим розподілом у часі вегетативної та генеративної фази розвитку;

9. У процесі дослідження серед колекційного матеріалу було виділено групу зразків, які відрі-

\section{БІБЛІОГРАФІЯ}

1. Генофонд и селекция крупяных культур. Гречиха / [Фесенко Н. В., Фесеанко Н. Н., Романова О. И., Алексеева Е. С., Суворова Г. Н.] ; под ред. В. А. Драгавцева. - СПб. : ГНЦ РФ ВИР, 2006. - $196 \mathrm{c}$.

2. Ефименко Д. Я. Гречиха / Д. Я. Ефименко, Г. И. Барабаш. - М. : ВО Агропромиздат, 1990. - $192 \mathrm{c}$.

3. Кротов А. С. Крупяные культуры / А. С. Кротов // Культурная флора СССР. - Л., 1975. - C. 1-118.

4. Культура грачихи / [Алексеева Е. С., Малина М. М., Тараненко Л. К. и др.] // Ч.1. История культуры, ботанические и биологические особенности. - Каменец-Подольский : издатель Мошак М. И., 2005. - 192 с.

5. Методика проведення експертизи сортів гречки їстівної (Fagopyrum esculentum Moench) на відмінність, однорідність і стабільність [Електронний ресурс]. - Режим доступу : http://sops.gov.ua/pdfbooks/Metodiki/8.pdf.

6. Петелина Н. Н. Создание исходного материала для селекции крупноплодных сортов дип- зняються найвищим показником співвідношення зони плодоношення до зони гілкування UC0100650 та UC0100660 (Тернопільська обл.), UC0100653 (Хоростківська, Тернопільська обл.), UC0101725 (Львівська обл.), UC0101195 (Ілія, Мінська обл.), UC0102181 (Інзерская, Башкортостан), UKR008:01687 (Батир, Татарстан) та інші.

лоидной гречихи / Н. Н. Петелина // Науч. тр. ВНИИЗбК. - Орёл, 1971. - Т.3. - С. 128-135.

7. Сірик П. А. Біологія кореневої системи гречки / П. А. Сірик // Н.т. - Т. IX. - К., 1959. - 95 с.

8. Тараненко Л. К. Генетическое обоснование совершенствования методов селекции гречихи Fagopyrum esculentum Moench : дисс. ... д.б.н. : 06.01.05. - X., 1989. - $383 \mathrm{c}$.

9. Тригуб О. В., Ляшенко В. В. Взаємозв'язок елементів архітектоніки рослини 3 урожайними характеристиками у сортозразків гречки звичайної (Fagopyrum esculentum Moench.) / О. В. Тригуб, В. В. Ляшенко // Вісник Полтавської державної аграрної академії. - №3. - 2013. - С. 49-55.

10. Фесенко Н. В. Селекция и семеноводство гречихи / Н. В. Фесенко. - М. : Колос, 1983. $190 \mathrm{c}$.

11. Широкий уніфікований класифікатор роду Гречки (Fagopyrum Mill.) [Тригуб O. В., Харченко Ю. В., Рябчун В. К., Григоращенко Л. В., Докукіна К. І.]. - Устимівка, 2013. - 54 с. 